\title{
ZSIGMOND HUSZITA HADJÁRATAINAK ELSŐ FELÉT (1420-1422) BEFOLYÁSOLÓ GAZDASÁGI ÉS FÖLDRAJZI TÉNYEZŐK
}

\section{Szerzők:}

Varga Imre Solt

Debreceni Egyetem

Szerző e-mail címe:

ordularyildirim@gmail.com

\section{Lektorok:}

Bárány Attila (Prof. Dr.)

Debreceni Egyetem

Mező Ferenc (PhD)

Eszterházy Károly Egyetem

...és további két anonim lektor

\begin{abstract}
Absztrakt
Ez a tanulmány Luxemburgi Zsigmond huszita hadjáratának (1420-22) első felére összpontosít, és különös figyelmet fordít annak gazdasági és földrajzi tényezőire, mert ezek jelentősen befolyásolták az egész háború kimenetelét. Ilyen tényezők a terep és viszonyai, az éghajlat és az időjárás, vagy ami azt illeti, maga a pénz, amelyek mind megfigyelhető hatással voltak mind az egész hadjáratra, mind az egyes katonákra.
\end{abstract}

Kulcsszavak: háború, husziták, történeti földrajz

Diszciplínák: történelem, földrajz

\begin{abstract}
ECONOMIC AND GEOGRAPHIC INFLUENTLAL FACTORS OF THE FIRST HALF OF SIGISMUND'S HUSSITE CAMPAIGNS (1420-1422)
\end{abstract}

This study focuses on the first half of Sigismund of Luxemburg's Hussite campaign (1420-22) and pays special attention to the economic and geographical factors of the campaign because these affected the outcome of the whole war significantly. Such factors include terrain and its relations, climate and weather, or, for that matter, money itself, all of which had an observable effect both on the entire campaign and on the individual soldiers as well.

Keywords: war, Hussites, historical geography

Disciplines: history, geography

Varga Imre Solt (2020): Zsigmond huszita hadjáratainak első felét (1420-1422) befolyásoló gazdasági és földrajzi tényezők. Lélektan és hadviselés - interdiszciplináris folyóirat, II. évf. 2020/2. szám. 59-71. doi: 10.35404/LH.2020.2.59 
A huszita háborúk jelentős szerepet töltöttek be a XV. századi Európában, utóhatásaikkal együtt évtizedekig megoldatlan problémát helyezve mind a katolikus keresztény világra, mind a közép-európai államokra. Ezen háborúk kezdetében a magyar csapatok központi szerepet töltöttek be, hiszen Luxemburgi Zsigmondot, mint a cseh trón örökösét a magyar csapatok támogatták. Ennek eseménytörténeti részéről Bánlaky József (1935) A magyar nemzet hadtörténelme, illetve TóthSzabó Pál (1917) A cseh-huszita mozgalmak és uralom története Magyarországon címú könyvekben is alapjaiban pontosan írják le a történéseket, mindazonáltal egyikük sem tért ki és térhetett ki ezen hadjáratok gazdasági vonulatára, illetve a földrajz több összetevős befolyásoló szerepére.

\section{Előzmények}

Alapvetően az előzményeket két szálra lehet bontani: a huszita szálra és a magyar szálra. A huszita szál akkor kezdődik, mikor a konstanzi zsinaton (1414-1418) Zsigmond az általa biztosított menlevél ellenére hagyta, hogy Husz Jánost elfogják, majd hosszú pereskedés után máglyahalálra ítéljék, melyet 1415-ben végre is hajtottak. A már ettől kezdve is kialakuló feszültséget Luxemburgi Vencel 1419. augusztus 16-án bekövetkezett halála csak súlyosbította.

A trónörökös egyértelműen Luxemburgi Zsigmond volt, hiszen Vencel már a XV. század elején birodalma vikáriusává tette, így ezt a husziták jelentős része sem vont kétségbe, egészen addig, amíg a boroszlói birodalmi gyúlésen a husziták elleni keresztes hadjárat indításáról határoztak (Tóth-Szabó, 1917). Zsigmond a bautzenieknek írt 1420 . március 15-i levelében kijelentette, hogy legyőzi a huszitákat és visszatéríti őket a katolikus hitre (Mályusz és Borsa, 2001: Zsigmondkori Oklevéltár, VII. 1492. sz.). Erre jött válaszként a prágaiak határozata, melyben a keresztesek elleni védekezésre szólították fel a huszitákat (Mályusz és Borsa, 2001: Zsigmondkori Oklevéltár, VII. 1577. sz.), illetve április 20-án Wartenberg Čeněk prágai fővárnagy és a cseh rendek egy levélben felsorolják, miért nem fogadják el Zsigmondot királyuknak (Mályusz és Borsa, 2001: Zsigmondkori Oklevéltár, VII. 1640. sz.).

A magyar szálat kibontva azt láthatjuk, hogy a Magyar Királyság elég aktív külpolitikát folytat, melynek egyik negatív velejárója, hogy a magyar haderőnek több fronton is helyt kell állnia. Egyrészt Velencével is háborúban állt, s bár 1419 októberében Seravallet és Bellunot is elfoglalta (Mályusz és Borsa, 2001: Zsigmondkori Oklevéltár, VII. 1024. sz.) és 1420. január 17-én Velence felkérte a bizánci követet arra, hogy közvetítsen békét a két fél között (Mályusz és Borsa, 2001: Zsigmondkori Oklevéltár, VII. 1269. sz.), ennek sikertelenségére nem utal más jel, mint az, hogy az utolsó dalmát városokat, Spalatot (ma Split) és Traut (ma Trogir) 1420 májusában Zsigmond végleg elvesztette.

Emellett az Oszmán Birodalom is aktivizálni kezdte magát, s 1417-ben elfoglalta Szörényvárat, mely a déli végvárrendszer keleti oszlopa volt. Ennek visszafoglalására indult Zsigmond 1419 ôszén (Mályusz és Borsa, 2001: Zsigmondkori Oklevéltár, VII. 907. sz.), s bár sikerült Szörényvárat visszavenni, a török csapatok ettől kezdve újra nyomás alatt tartották nemcsak az ütközőállamokat, hanem a magyar területeket is 
(Pósán, 2019), mely szintúgy jelentős költségeket és erőket emésztett vett, mint a Velence elleni háború.

A harmadik jelentős ügy, amelyet Zsigmondnak szem előtt kellett tartania, az a Német Lovagrend és a lengyel-litvánok közti béke létrehozása. Michael Küchmeister nagymester és II. Ulászló lengyel király is beleegyezett abba, hogy Zsigmond legyen a döntőbíró a két fél ügyében, melyet a boroszlói birodalmi gyúlést megelőzően, 1420. január 6-án ejtettek meg. Zsigmond azonban politikai megfontoltságból olyan döntést hozott, mely nem oldotta meg, hanem fenntartotta a problémát (Pósán, 2019).

Mindemellett azt is fontos megemlíteni, hogy Zsigmond csak 1419 februárjában lépett a Magyar Királyság területére (Engel és C. Tóth, 2005), melyet a konstanzi zsinat és európai utazásai miatt 5 évre elhagyott, így minden bel- és külpolitikai probléma rövid időn belüli megoldása lett a feladat.

Összességében tehát azt lehet mondani, hogy a Magyar Királyság csak jóval csekélyebb figyelmet és anyagi költséget tudott belefektetni a husziták elleni hadjáratokba, köszönhetően az egyéb fennálló problémáknak.

\section{Rövid eseménytörténeti áttekintés}

Annak ellenére, hogy a husziták kezdetben elismerték Zsigmond jogát a cseh trónra, követeléseikkel, akarva-akaratlan, de nem érhettek el mást, csak háborút. A később négy prágai cikkelyként ismert követelések (1420. 07. 04.) még csak körvonalazódtak (TóthSzabó, 1917), ennek ellenére egyértelmú, hogy Zsigmond nem fogadhatta el a husziták követeléseit. Voltaképpen önmagában az is sértő, hogy a jogos trónörökösnek részben polgárok és jobbágyok, részben nemesek szabnak feltételeket.

Szintén nem elhanyagolandó szempont az sem, hogy a pápa által eretneknek nyilvánított huszitákkal való megegyezés nem illett volna össze a nyugati kereszténység szakadását nemrég megakadályozó Zsigmonddal, nem beszélve arról, hogy így szembekerült volna a pápával is. Ezen szempontok alapján tehát azt lehet mondani, hogy a harc elkerülhetetlen volt.

Az első hadjárat a husziták ellen 1420 áprilisában indult, Boroszlóból indulva Hradec Králové-n át érkeztek Vyšehrad alá, ahol július 13-án hozzákezdtek Prága ostromához. (Bánlaky, 1935) Maga a hadjárat nem zárult teljes sikerrel. Egyrészt azért, mert bár Vyšehrad és a Hradzsin Zsigmond kezébe került, az utóbbi helyen meg is koronázták 1420. július 28-án (Bánlaky, 1935), azonban Prágát teljesen nem tudták bevenni, köszönhetően az elszántan védekező prágaiak makacs ellenállásának, illetve annak, hogy Jan Žižka egy jelentős - Turnbull által 9000 főre becsült serege tartott Prágába, és elfoglalta a Vítkovhegyet, fenyegetést jelentve a Zsigmond vezette ostromló seregre (Turnbull, 2004). Másrészt azért sem, mert a birodalmi csapatok vezére, Rosenberg Ulrik nem tudott seregtestével egyesülni Prága alatt Zsigmonddal, ugyanis a husziták Tabor városánál legyőzték a birodalmi sereget 1420 júniusának végén. (Mályusz és Borsa, 2001: Zsigmondkori Oklevéltár, VII. 1915. sz.) S bár Zsigmond a cseh koronát meg tudta szerezni, a huszita kérdést közel sem tudta megoldani.

1420. november 1-jén Zsigmond Vyšehradnál vereséget szenvedett a huszitáktól 
(Mályusz és Borsa, 2001: Zsigmondkori Oklevéltár, VII. 2295. sz.), mely egyértelművé tette mindenki előtt, hogy a huszitizmussal kapcsolatos problémát nem lesz egyszerú megszüntetni. Emellett ez volt az elsô alkalom, hogy egy jelentősebb csatában a husziták legyőzték a magyar csapatokat. Alapvetően itt még nem beszélhetünk jelentős magyar veszteségről, ugyanis minden jel arra utal, hogy Zsigmond elsősorban a cseh csapategységekre hagyatkozott a csatában, ugyanis egy november 5-én Čáslavban írt levélben a prágaiak panaszkodtak Zsigmond kegyetlenségére, ugyanis szerintük szánt szándékkel küldte a halálba a cseh urakat és lovagokat (Mályusz és Borsa, 2001: Zsigmondkori Oklevéltár, VII. 2298. sz.).

1421 tavaszán a husziták ellentámadása sikeresen visszaszorította a magyarokat, akiknek nyárra vissza kellett vonulni a Magyar Királyság határain belülre (Bánlaky, 1935).

$\mathrm{Az}$ 1421. június elsejére összehívott cseh országgyúlés Č́slavban újra kimondta a Luxemburg-ház trónfosztását, megerôsítve a néhány hónappal korábbi kijelentést, illetve semmisnek deklarálva Zsigmond koronázását, kijelentve, hogy a prágai cikkelyeket mindenképp meg kell védeni (Tóth-Szabó, 1917).

1421. szeptember 28-án megtartották Habsburg Albert és Luxemburgi Erzsébet esküvőjét, mellyel Zsigmond jelentős szövetségesre tett szert az osztrák herceg személyében, s a következő hónapban meg is indította a hadjáratot Alberttel a husziták ellen. A kezdeti sikerek ellenére (december 22. kolíni győzelem) 1422 januárjában a husziták végül vereséget mértek a magyar seregre Havlíčkův Brodnál, mellyel megszilárdították hatalmukat, s bár 1424-ben Albert osztrák csapataival és egy kisebb magyar segédcsapattal kisebb területeket, várakat elfoglalt, a husziták hatalmát ezzel nem veszélyeztették (Tóth-Szabó, 1917; Bánlaky, 1935).

\section{Gazdasági tényezők}

„A háborúhoz három dolog kell: pénz, pénz és pénz!" - Raimondo Montecuccoli.

Habár a fenti idézet nem tartalmaz mindent, ami a háborúhoz szükséges, egy dologban igaza van: ha van pénz, minden van, beleértve a fegyvert, a katonákat, az utánpótlást. Röviden a pénz a háború multifunkcionális eszköze, mellyel az erőforrások egy jelentős részét elő lehetett teremteni.

Zsigmond pénzügyei a hosszútávú külföldi tartózkodások és a háborúk miatt elég komplikáltak voltak, emiatt gyakran került pénzszúkébe a király, amely nem volt a legkedvezőbb kiindulópontja a huszita hadjáratok pénzügyi hátterének. Az első példa erre az, hogy Zsigmond az 1412 novemberétől 1419 februárjáig (Engel és C. Tóth, 2005) tartó európai utazásai alatt jelentős hiteleket vett fel, mely tartozások egy része még a huszita háborúk kitörésekor is élt. Ilyen volt az az eset, miszerint VII. (Szakállas) Lajos bajor herceg 1419. november 19-én felszólította Zsigmondot, hogy az általa felvett 23000 forint értékű tartozását rendezze.(Mályusz és Borsa, 2001: Zsigmondkori Oklevéltár, VII. 1110. sz.).Egy még jelentősebb összegről tanúskodik az 1420. január 23-án Boroszlóban kelt oklevél, miszerint Zsigmond korábban János hollandi gróftól és bajor hercegtől 32000 aranyforintot vett föl (igaz, mindezt hozzácsapta Luxemburg hercegség zálogösszegéhez, így a végső számításaimba nem kerül- 
tek bele - Mályusz és Borsa, 2001: Zsigmondkori Oklevéltár, VII. 1289. sz.) Ha ez nem lenne elég, Zsigmond 1420. augusztus 7én - tehát az első hadjárat után közvetlenül elzálogosított néhány ékszert azért, hogy XVI. (Gazdag) Henrik bajor herceg irányába fennálló tartozását törleszteni tudja (Mályusz és Borsa, 2001: Zsigmondkori Oklevéltár, VII. 2048. sz.) Vagyis Zsigmond úgy kezdett bele a husziták elleni háborúba, hogy 29000 forint értékű hátraléka volt!

Magától értetődően voltak bevételei is: az alapvető királyi bevételek mellett a zálogosításból folyt be Zsigmondnak jelentős összeg, melyet a hadjáratok pénzelésére fordíthatott. Az első hadjárat elôtt Szentgyörgyi és Bazini György grófnak Sempte várat a hozzá tartozó uradalommal és vámokkal (Mályusz és Borsa, 2001: Zsigmondkori Oklevéltár, VII. 1595. sz.), s bár az összeget nem említi, a későbbiekben említésre kerülő birtokok, a korábban eladományozott birtokokat tekintve (Incze, 2012, 2016), illetve Sempte (ma Šintava) várának jelentős szerepét tekintve mintegy 10-13000 forint értékű összegről beszélhetünk. Emellett április 17-én Zsigmond a boroszlói polgároknak 1177 forintos értékben zálogosít el ezüst tárgyakat (Mályusz és Borsa, 2001: Zsigmondkori Oklevéltár, VII. 1621. sz.), mely önmagában nem számít jelentős összegnek egy hadjárat finanszírozása szempontjából, de részösszegként korántsem alábecsülendő. Emellett még lehet számolni olyan összegekkel, mint például a tárnoki városok adójával. Leuchtenburgi Smilo soproni kapitány 1420. július 1-jén például 400 forintot vett át a király részére a soproniak György-napi adójaként (Mályusz és Borsa, 2001: Zsigmondkori Oklevéltár, VII.
1919. sz.). Igaz, ez már nem érkezhetett meg a hadjárat előtt, azonban azt követően igen, vagyis a katonák fizetésében szerepet játszhatott.

Persze ezen összegek egy része Zsigmond mindennapi szükségleteit fedezte, a maradék összeg már megfelelő volt egy kisebb létszámú sereget fizetni, vagy a tartozás egy részét letudni. Az mindenesetre elmondható, hogy a rendelkezésre álló összeg alapján az első hadjáraton résztvevő sereg száma közel sem lehetett olyan jelentős, mint azt Bánlaky (1935) becsülte (ő mintegy 70-80 000 főről írt könyvében). Rázsó Gyula szerint az ország népességének mintegy 1,4-1,6\%-a volt hadra fogható, ami alapján - tekintve a 15. század közepére jellemző 3,2-3,3 milliós népességet nagyjából 44000 és 52000 becsülhető a vizsgált korszakban a magyar hadsereg létszáma (Tóth, 2016). S mint ahogy fent említettem, ez a sereg ekkoriban semmiképp sem mozoghatott együtt, hiszen háború folyt Velencével, illetve számítani lehetett a török rablóhadjáratokra is.

1421-re már nyilvánvalóvá vált az előző évi kudarcok alapján, hogy jelentősebb sereget kell bevetni Csehország megszerzése érdekében. Ennek okán Zsigmond már jóval jelentősebb összegeket szerzett.

Két április 6-án kelt oklevélben Zsigmond utasítja valamennyi alattvalóját, hogy: Haubel hainburgi zsidó kereskedőnek fizessék ki a tartozásaikat, s a pozsonyi bírót megbízza, hogy a behajtásnál az összeg harmadát vegye át Haubeltől nyugta ellenében (Borsa és C. Tóth, 2003: Zsigmondkori Oklevéltár, VIII.377. sz.); illetve Isser brucki zsidó kereskedővel hasonlóan egyezett meg, csak itt az összeg felét vetette át a pozsonyi bíróval 
nyugta ellenében (Borsa és C. Tóth, 2003: Zsigmondkori Oklevéltár, VIII. 378. sz.). Az összeget itt ezekben az esetekben sem adta meg az oklevélben, de itt is jelentős, több ezer forintos nagyságrendekről beszélhetünk. Később, 1421. július 24-én Zsigmond felszólította a pozsonyiakat, hogy Izrael, Haybel és Aron nevú pozsonyi zsidóknak minden olyan polgár fizesse ki a tartozását, akik eddig nem tették (Borsa és C. Tóth, 2003: Zsigmondkori Oklevéltár, VIII. 814. sz.); illetve október 4-én Zsigmond megbízta Garai Miklós nádort, Kanizsai Istvánt és több nemest, az előbb említett pozsonyi zsidóknak, miután elǔzték őket Ausztriából az adósaik, szolgáltassanak igazságot és segítsenek beszedni nekik a tartozásokat (Borsa és C. Tóth, 2003: Zsigmondkori Oklevéltár, VIII. 1033. sz.).

Összeget ezeken sem említett, azonban, tekintve, hogy két boroszlói kereskedő képes volt közel 1200 forintot adni az uralkodónak a zálogtárgyakért cserébe, a két zsidó kereskedő, melyeknek az oklevelek alapján mind Magyarországon, mind az Osztrák Hercegségben voltak adósaik szép számmal, képesek lehettek legalább hasonló, de inkább magasabb összeget beszedni fejenként az uralkodó segítségével. Az általam becsült összeg, melyet a kereskedők beszedhettek, fejenként 1500-2000 forintra rúghattak, melyek harmada, illetve fele, melyet a kereskedők a királynak kölcsönöztek, mintegy 1500-1800 forintnak megfelelő a fenti adatok, illetve a becslésem alapján.

Csupán érdekességképp: október 13-i keltezéssel Zsigmond levelet írt vejének, Albertnek, hogy lánya udvarhölgyének, Annának 600 guldent fizessen ki 1422. április 23-ig (Borsa és C. Tóth, 2003: Zsigmondkori Oklevéltár,
VIII.1049. sz.). Hogy miért tartozott Zsigmond egy udvarhölgynek 600 guldennel, illetve, hogy azt miért vejének, Albertnek kell megfizetnie, az valószínúleg örök rejtély marad, de maga a tény, hogy Zsigmond még egyszerű udvarhölgyektől is vett fel pénzt, némiképp komikus.

Nem sokkal később, április 10-én Zsigmond Magyarbródban (ma Uherský Brod) kelt két levelében felszólította Pozsony és Kassa városokat, hogy az elmaradt királynéi újévi ajándékokat azonnal fizessék ki (Borsa és C. Tóth, 2003: Zsigmondkori Oklevéltár, VIII.385. és 386. sz.). Természetesen az összeg nem lehetett túlontúl jelentős, mintegy 500-1000 forint a két összeg együttvéve, azonban ezen összegek is jelentősen hozzájárultak a hadjárathoz. Hasonlóan ehhez, július 18-i levelében Sólyagi Sebestyén, Tamási László királyi ajtónállómester familiárisa elismeri, hogy az 1420. és 1421. évben Sopron városa 600-600 dénárt fizetett (Borsa és C. Tóth, 2003: Zsigmondkori Oklevéltár, VIII.775. sz.). Habár nincs egyértelmû utalás rá a szövegben, de többek közt ezt és az ehhez hasonló regálé jövedelmeket is felhasználhatta, illetve fel is használta Zsigmond a hadjárat finanszírozására.

A legjelentősebb összegeket persze a zálogosítások hozták 1421-ben is. Április 1-jén Brnoban Darnóc (ma Slatinski Drenovac) várát és a hozzá tartozó uradalmat Garai Dezső macsói bánnak és Garai Jánosnak 7000 forintért elzálogosítja (Borsa és C. Tóth, 2003: Zsigmondkori Oklevéltár, VIII. 355. sz.), illetve 3 nappal később, április 4-én örök adományul nekik is adta a birtokot (Borsa és C. Tóth, 2003: Zsigmondkori Oklevéltár, VIII. 366. sz.). Április 20-án kelt oklevélben 
Zsigmond 10000 aranyforintért elzálogosítja Rezi várat a hozzá tartozó uradalommal, illetve Keszthely városával, továbbá Pölöske vár felét Medvéi János zágrábi püspök királyi és királynéi főkancellárnak és testvérének, Rudolfnak (Borsa és C. Tóth, 2003: Zsigmondkori Oklevéltár, VIII.429. sz.) Nem sokkal később, május 25-én Szécsényi Lászlónak zálogosítja el 5000 forintos értékben a Nógrád megyei pataki várat a hozzá tartozó uradalommal, vámmal, illetve a Dehtar királyi birtokot (Borsa és C. Tóth, 2003: Zsigmondkori Oklevéltár, VIII.551. sz.) Ezek mellett augusztus 24-én szántói Lack Dávid volt szlavón bánnak zálogosította el Kentheleke, Arokalya, Sofalwa és Orozfalw, illetve a Kolozs megyei Puzthakamaras és Zombaththeleke birtokokat minden tartozékukkal és bevételeikkel együtt 4000 forintért (Borsa és C. Tóth, 2003: Zsigmondkori Oklevéltár, VIII.888. sz.); végül november 23án Maróti Jánosnak és Maróti Lászlónak zálogosította el a magtalanul elhalt Vadaz-i Farkas Illés minden birtokát, összesen 3100 forint értékben (Borsa és C. Tóth, 2003: Zsigmondkori Oklevéltár, VIII.1175. sz.).

Ha ezen összegeket összeadjuk, akkor Zsigmond azon bevételei, melyekről külön rendelkezett, illetve zálogosításból folytak be, nagyjából 35-37 000 forintnak felelnek meg, ami legalább duplája, de inkább triplája az 1420-ban, hasonlóképp befolyt összegnek, melyet 12-15000 forint közzé tehetünk az adatok alapján. Ez az összeg már jelentősebb létszámú hadsereg fizetését is biztosította, vagyis az 1420-as hadjáratban résztvevőknél jóval nagyobb létszámú magyar seregről beszélhetünk.
1422 elején a magyar csapatok vissza lettek nyomva egészen a Magyar Királyság területéig. Ettől kezdve a magyar csapatok a védekezésre fektették a hangsúlyt, valószínúsíthetően alacsonyabb létszámú seregtesteket állomásoztattak az észak-nyugati vármegyékben, minek okán kevesebb plusz bevétel is elegendő volt a csapatok ellátására és fegyverben tartására (Tóth, 1916).

1422. május 8-án Maróti Jánosnak volt macsói bán és fia, Lászlónak 15000 forintért elzálogosította Bodolyai Péter összes, illetve Orbonai Olasz László szlavóniai birtokait (Borsa és C. Tóth, 2004: Zsigmondkori Oklevéltár, IX-513. sz.); Garai Miklós nádornak előbb június 6-án 6840 (Borsa és C. Tóth, 2004: Zsigmondkori Oklevéltár, IX-608. sz.), majd július 3-án további 6120, vagyis összesen 13000 forintos értékben zálogosította el Zsigmond Komárom várát a hozzá tartozó jelentős méretű birtokkal, benne Komárom és Neszmély oppidumokkal (Borsa és C. Tóth, 2004: Zsigmondkori Oklevéltár, IX-754. sz.). Zsigmond Garai Jánosnak a június 29-én kelt oklevél szerint 12000 forintért cserébe Tállya, Tokaj és Tarcal településeket zálogba adta (Borsa és C. Tóth, 2004: Zsigmondkori Oklevéltár, IX-734. sz.). Július 4-én Ropuli János özvegyének 4000 forintért cserébe zálogba adta Garygnycha birtokot (Borsa és C. Tóth, 2004: Zsigmondkori Oklevéltár, IX760. sz.), illetve július 9-én Kapler Péter volt pozsonyi ispánnak zálogosította el Köpcsény (ma Kittsee) várát és a hozzá tartozó birtokot 9000 forintért cserébe (Borsa és C. Tóth, 2004: Zsigmondkori Oklevéltár, IX-777. sz.). Összességében el lehet mondani, hogy 1422ben is jelentős bevételei származtak az uralkodónak a zálogosításból, melyek jelentős részét 
a katonák kifizetésére volt kénytelen beszerezni. Az 1422-es évet mindössze augusztus 31-ig vizsgáltampénzügyi szempontból, ugyanis ezt követően Zsigmond már a lengyel kérdéssel foglalkozott inkább, ugyanis küszöbön állt egy magyar-lengyel háború is (TóthSzabó, 1917), amely kirobbanása esetén plusz jövedelmekre lett volna szükség, így nem lett volna egyértelmű, hogy a befolyt összegek milyen arányban oszlottak el. Így is, mindössze 7 hónap alatt 53000 forint folyt be, mely összeg az 1421-1422 telén zajló háború támadó sereg létszámát minden korábbinál magasabbra engedi becsülni. Persze ez a szám ugyancsak nem éri el a Bánlaky (1935) által feltételezett 60000 foot, hiszen ekkora sereget ilyen kevés pénzből fizetni akkor se lehetett volna, ha belevesszük, hogy egy részük ún. hűbérúr iránti kötelezettségből harcoló volt, akiknek a jutalmazása nem törvényszerűen pénzben, hanem birtokkal vagy egyéb joggyakorlással történt (Bárány, 2017), legyen az akármilyen szerény is, nem is beszélve a következő fejezetben kibontásra kerülő földrajzi okokról, melyek miatt ez a szám jócskán magasabb, mint ami a valóságban lehetett. Tóth Dominik tanulmányában kifejti, hogy egy - igaz, Mátyás korabeli pénzértékekkel számolva (korábbról adat híján nem tudunk számításokat végezni) - 700 fős, lovasokból és gyalogosokból álló segédcsapat (100 vértes lovas, 200 huszár, lovasonként három, azaz összesen 900 lóval, illetve 100 pajzsos 300 „közgyalogos” és puskás) negyedévi zsoldja 14500 forint volt (Tóth, 2016, 2018). Persze hiányzik az az adat, amely legalább megengedné a becslést, miszerint milyen arányban voltak a zsoldért harcolók és a húbérúr iránti kötelességből harcolók aránya ahhoz, hogy megközelítőleg pontos létszámadatot tudjunk becsülni, ám ahhoz a fenti adatok elegendőek, hogy a Bánlaky által közölt létszámadatokat legalább 8-cal kell osztani ahhoz, hogy a valóságoshoz jobban közelítő értéket kapjunk.

Összegezve az eddigieket, az mindenképp elmondható, hogy a befolyt összegek, illetve a korábbi szakirodalmak által lejegyzett létszámadatok közel sem fedik egymást, hiszen egy lovas zsoldos katona 15 forintos havi zsoldért harcolt (függően a fizetőeszköz értékétől, a területtől, az évszaktól, a lovak számától stb. Tóth, 2016). Bár Zsigmond idejében csekély zsoldosseregről beszélhetünk, a többség hűbérura iránti kötelezettségének okán harcolt, ám ezek ellátása is többe kerülne egy hónapra, mint a fennálló összeg teljes értéke, ha a Bánlaky-féle létszámadatokat vennénk alapul.

\section{Földrajzi tényezők}

A földrajz hatása a történelem különböző részeire elég jelentős, ennek kutatására jött létre az a segédtudomány, melyet történeti földrajznak nevezünk. A történeti földrajz foglalkozik azokkal az adatokkal, területekkel, melyekkel a földrajztudomány is foglalkozik, csak ezt visszavetíti a múltra. A földrajzi adottságok egy-egy társadalomra gyakorolt hatása elég jelentős, habár önmagában nem determinálja kizárólagosan a következményeket. Bár a történeti földrajz kutatása a szocialista időszak alatt tiltott volt, a '80-as évektől kezdve újjáéledt a segédtudomány (Csíki, Halmosi és Tóth, 2006).

Hogy mennyire volt jelentős a földrajz szerepe a háborúban? Erre egy elég jó példa lehet a következő: Napóleon 1812-es orosz 
hadjáratának kudarca részben legalábbis annak köszönhető, hogy egy 1812-es vulkánkitörésnek köszönhetően a légkörbe jutó vulkáni aeroszolok miatt a Föld évi átlaghőmérséklete némiképp lecsökkent (Szilágyi, 2004). Ez okozta, hogy Napóleon várakozásaival ellentétben az orosz tél nem november közepén, hanem egy hónappal korábban, október első felében érkezett meg, amely nehezítette az utánpótlás biztosítását, illetve a katonák nem megfelelő öltözéke a fagyás általi sérülést, sok esetben halálra fagyást is eredményezett, mindezzel megnehezítve a harcokat az oroszok ellen (Szilágyi, 2004).

Mindezek fényében talán érthetőbb, miért kell olyan szempontokat figyelembe venni, mint a domborzat, az időjárás, a vízrajz vagy a településhálózat, melyek számottevő hatással bírhattak a hadjárat menetére, még ha a végeredményt nem is önmagukban határozták meg (v.ö.: Szun-ce: A hadviselés törvényei).

A domborzati viszonyok több oldalról is befolyásolhatják a hadjáratot. Egyrészt a felvonulási területet is meghatározzák. Egy zömében lapos, alföldi területen a felvonulási terület sokkal nagyobb, mint a hegyvidékeken, ahol ez koncentrálódik a folyóvölgyekre. A felvonulási terület mérete többek közt azért is fontos, mert a jóval több lehetôséget biztosít a tervezésre, könnyebb egyben tartani a csapategységeket, illetve a felderítést is megkönnyíti, ami az ellenséges egység(ek) mozgására adott választ felgyorsítja (v.ö.: Szun-ce: A hadviselés törvényei). Ezen felül fontos tényező, hogy a husziták a harci szekereken mozgatták a gyalogságot is, így, ha nem állt fel időben a wagenburg, könnyen bajba kerültek volna a harci szekerek legénységén kívül a szállított gyalogos csapat- egységek is (Tóth, 2017). A hegyvidéki területeken a völgyekre korlátozódó mozgás csökkenti a reakcióidőt, elnyújtja a menetoszlopot, vagyis nagyobb felületet ad a támadásoknak. Bárány Attila (2013) szerint egy 15000 fős sereg 50 napra elegendő ellátmányához 1874 szekér, illetve 9400 ló kellett, s csak ennek a menetoszlopnak a hossza $9 \mathrm{~km}$ hosszú volt, a hadsereg nélkül! Tovább nehezíti a felderítést, illetve nagyobb teret ad a „hazai pálya” előnyét élvező csapatoknak a rajtaütésekre, miként azt a havasalföldi csapatok tették 1330-ban Károly Róbert ellenében a posadai csatában (Veszprémy és Somogyi, 2014). Az általunk vizsgált időszak alatt és területen, az eseményeket az Engel és C. Tóth-féle (2005) itineráriummal egyeztetve, a várakozásoknak megfelelően Zsigmond, illetve a magyar hadsereg a legtöbb esetben próbált az alacsonyabb térszínen maradni, illetve a csaták jelentős része is ezen a területen zajlott le (1. ábra).

Számottevő hatása van a vízrajznak is. Bárány Attila katonai logisztikával foglalkozó tanulmánya szerint egy felnőtt férfi átlag 3,74,2 liter vizet fogyasztott naponta, illetve egy lónak nagyjából 40 liter vízre volt szüksége (Bárány, 2013). Egy 5000 fős lovas sereg fejenként három lóval számolunk - nagyjából 620000 liter vizet fogyasztott tehát naponta. A XV. század első felében a Cseh Királyságra jellemző volt a mainál hűvösebb, csapadékosabb éghajlat, emellett nagyon jó vízrajzi adottságokkal rendelkezett (Rácz, 2006), a hadszíntéren keresztülfolyó Elba és Moldva folyó mellett több patak és kisebb folyó is biztosította a hadsereg számára az ivóvizet, mint például a Kuttenberg (ma Kutná Hora) mellett folyó Vrchlice. 
1. ábra: Cseh-és Morvaország jelentösebb városai és medencéi a hadjáratok térségében (Sajät szuerkesztés az. QGIS program Streetmap térképe alapján, 2020. 04. 29.)

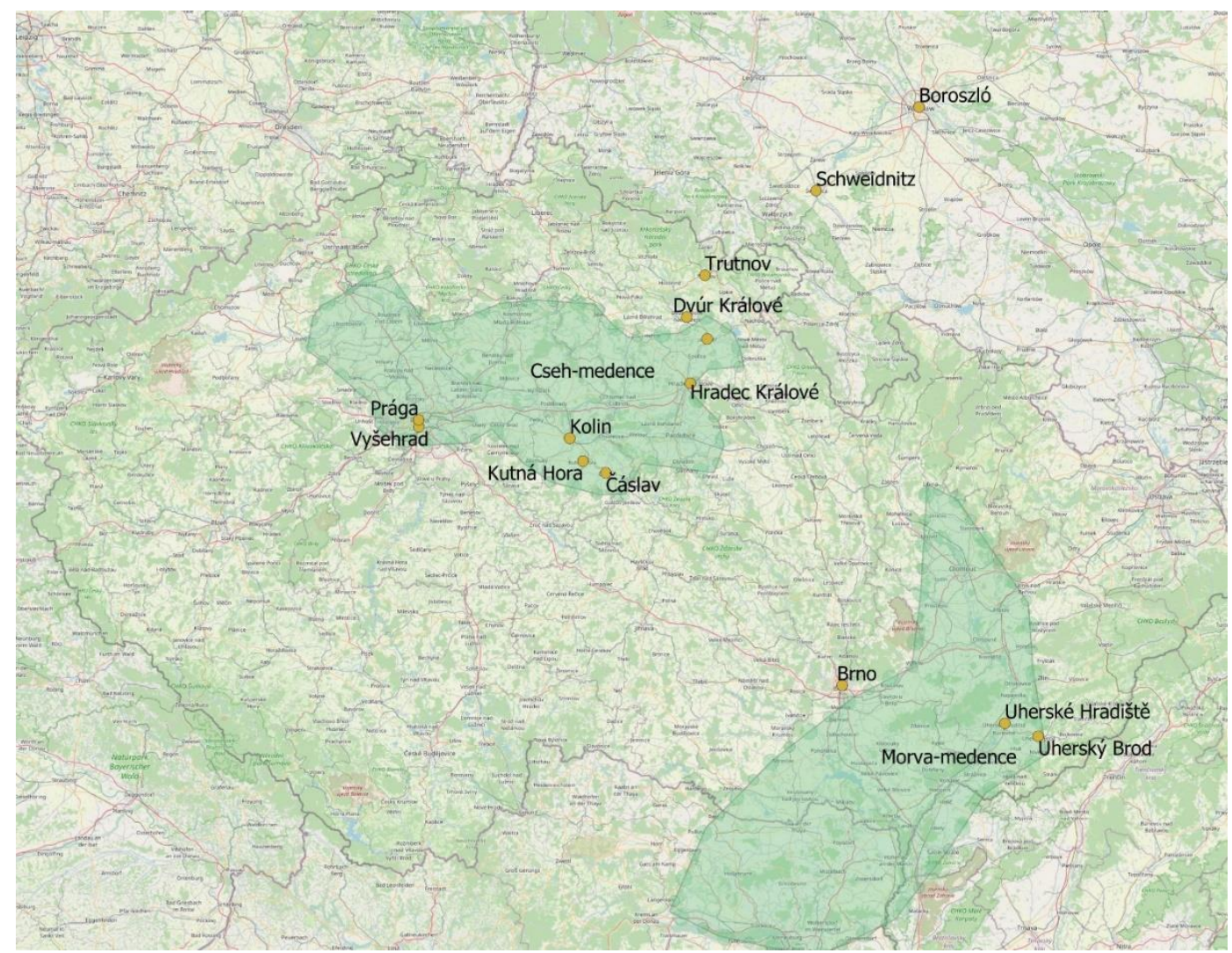

Az éghajlati tényezők lényegessége leginkább a hadjárat lefolyására adott időintervallumot határozta meg. Ez a vizsgált esetben azért érdekes, mert nyári és téli hadjáratokról is tudunk, vagyis a hőmérséklet nem volt kizáró tényező, amely meglepő, hiszen Rácz Lajos kutatásai szerint az 1420-as években elég hideg és csapadékos volt a tél Csehországban (Rácz, 2006), vagyis nemcsak a hideggel, de a hó által keltett akadályokkal is meg kellett küzdenie a magyar csapatoknak. A szóba eső évek tavaszain kisebb csatározásokat említett mind Bánlaky József (1935), mind Tóth-Szabó Pál (Tóth-Szabó, 1917), vagyis jelentősebb csapatmozgások nem voltak, amiben a tavaszi áradások játszhatták a vezető szerepet, amelyek ekkoriban gyakran árvizekhez vezettek. A nyarak ezzel szemben szárazabbak voltak a korábbiaknál, amely megfelelő időjárást biztosított a hadjáratoknak (Rácz, 2006). 
A településföldrajz jellemzően azért kapott szignifikáns szerepet, mivel a jelentősebb méretû települések rendelkeztek olyan kereskedői élelmiszerraktárakkal, amely változó ideig képes volt a hadsereg ellátását biztosítani. Továbbá a városok kezében volt az a központi funkció, mely a környező területek fölös terményeinek adásvételét biztosította: a piactartási jog (Pósán, 2007). Ezenfelül a városfallal rendelkező városok menedéket biztosítottak egy esetleges vereséget követő visszavonuláskor, röviden biztosította a sereg védelmét is.

Összevetve a korabeli városi rangú településeket, illetve Zsigmond király itineráriumát (Engel és C. Tóth, 2005) azt az eredményt kaptam, hogy az esetleges útvonalon fekvő városok közti távolság nem haladta meg a 3035 kilométert, ami egy lovas seregnek egynapi útja volt, gyalogos sereg esetén kétnapi járóföld. Következésképp a hadseregnek nem kellett kétnapi adag élelmiszernél többet magukkal cipelniük, ami megkönnyítette a menetelést is.

Az eddigiekhez kötődik a gazdaságföldrajz szerepe is, legalábbis olyan aspektusból, hogy mely területeken lelhető fel azon mennyiségű élelmiszer, mely az adott hadseregnek pár napi adagját képes volt fedezni. Értelemszerūen az alacsonyabb térszíneken jelentősebb mezőgazdasági termelés volt, így az itt elhelyezkedő városokat volt érdemes útba ejteni, melyek ezeken a területeken töltöttek be valamilyen szinten központi funkciót (Pósán, 2007). Az 1420-as évekre emellett jellemző volt az is, hogy a terményeket nagyjából 5-7 nappal korábban be tudták takarítani (Rácz, 2006), ami a kedvezőbb időjárási feltételeket is bizonyítja, valamint a hadsereg élelmezését is meg- könnyítette. Önmagában egy katona napi fogyasztása nagyjából mintegy 1,5 kg kenyeret és $0,5 \mathrm{~kg}$ húst jelentett, míg egy lónak mintegy $6 \mathrm{~kg}$ gabona, illetve 7,5-8 kg szálastakarmány volt a napi fogyasztása (Bárány, 2013), ami az előbbi példát véve alapul - egy 5000 fős lovas seregnek, katonaként 3 lóval számolva, napi szinten $7500 \mathrm{~kg}$ kenyérre, $3750 \mathrm{~kg}$ húsra, 90000 kg gabonára és 120000 kg szálastakarmányra volt szüksége.

Érdemes végig gondolni, hogy egy többhetes, akár több hónapos hadi vállalkozás mekkora élelmiszerszükségletekkel, illetve ezáltal logisztikával járt, melyet a terület, melyen a hadjárat folyt, csak az aratást követően tudott stabilan biztosítani (Tóth, 2016 - a fiziológiai szükségletek lélektani hadviselés során történő felhasználásával kapcsolatban lásd: Mező, 2014).

Habár Csehország fejlett területnek számított a korabeli Közép-Európában, mezőgazdasági termelékenysége a huszita háborúk idején megcsappant, vagyis a területen éhezés volt tapasztalható (Palacky, 1984.), amely a háborús pusztításnak, illetve a husziták közé beállt földmûvesek által okozott munkaerôhiány okán jött létre, s nemcsak egy idegen, de a huszita seregtesteket sem tudták teljes egészében élelemmel ellátni.

\section{Konklúzió}

Alapvetően a fentebb leírtak egy kutatás részeredményeit képezik, az adatok feldolgozása, illetve a szakirodalom gyüjtése, vagy pontosan annak hiánya megnehezíti a kutatást, ugyanakkor az eddigi adatok biztatóak abban a tekintetben, hogy további eredmények várhatóak, melyek az itt leírtakat árnyalhatják. 
Az is kijelenthető, hogy mind a földrajzi, mind a gazdasági tényezők és adatok cáfolják a korábbi szakirodalmak (Bánlaky, 1935; TóthSzabó, 1917) létszámadatait, valamint egy olyan kutatási vonalat is biztosítanak, amely a hadjáratok pontosabb útvonalának feltérképezésére ad lehetőséget, mely a Zsigmond huszita háborúinak első részét új perspektívából mutathatja meg.

\section{Irodalom}

Bánlaky J. (1935): A magyar nemzet hadtörténelme. IX. kötet. Letöltés: 2020-04-22- Web: https://mek.oszk.hu/09400/09477/html Ltartalomjegyzek.html

Bárány A. (2013): Hadtáp és logisztika Angliában a százéves háború korában. In: Pósán L. és Veszprémy L. (szerk): A hadtáp volt maga a fegyver. Tanulmányok a középkori hadszervezet és katonai logisztika kérdéseiröl. Zrínyi Kiadó, Budapest. 59-115.

Bárány A., B. Szabó J. és Veszprémy L. (2017): A késő középkor hadtörténete (13871490). In: Hermann R. (szerk.): Magyarország hadtörténete I.: A kezdetektól 1526-ig. Zrínyi Kiadó, Budapest. 223-288.

Borsa I. és C. Tóth N. (2004): Zsigmondkori oklevéltár IX. (1422).. Magyar Orsqágos Levéltár kiadványai II., Forráskiadványok 41. Magyar Országos Levéltár, Budapest.

Borsa I. és C. Tóth N. (szerk.) (2003): Zsigmondkori oklevéltár VIII. (1421). Magyar Orsqágos Levéltár kiadványai II., Forráskiadványok 39. Magyar Országos Levéltár, Budapest.

Csíki T., Halmos K. és Tóth Á. (2006): A magyar társadalomtörténet-írás története a kezdetektől napjainkig. In: Bódy Zs. és Ö.
Kovács J. (szerk.): Bevezetés a társadalomtörténetbe. Osiris Kiadó, Budapest. 208-241. Engel P. és C. Tóth N. (2005): Itineraria regum et reginarum Hungariae (1382-1438). MTA Támogatott Kutatóhelyek Irodája, Budapest. 95-111.

Fa Á. (2010): Zsigmond király huszita harcai és hatásaik a magyar hadügyekre. Hadtudományi Szemle, 3. évf. 2. sz. 2010. 77-85.

Incze J. (2012): Luxemburgi Zsigmond: Segesd és Bártfa esete. In: Péterfi B., Vadas A., Mikó G. és Jakab P. (szerk.): Micae Mediaevales II. Fiatal történészek dolgozatai a középkori Magyarországról és Európáról. ELTE BTK Történelemtudományok Doktori Iskola, Tanulmányok - Konferenciák, 3. kötet. Komáromi Nyomda és Kiadó Kft, Budapest. 109-123.

Incze J. (2016): 360 évig zálogban. A Szepesség elzálogosítása. In: Fábián L., Gál J., Haraszti Szabó P. és Uhrin D. (szerk.): Micae Mediaevales V. Fiatal történészek dolgozatai a középkori Magyarországról és Európáról. ELTE BTK Történelemtudományok Doktori Iskola, Tanulmányok - Konferenciák, 9. kötet. Printtatu Kft, Budapest. 91-104.

Mályusz E. és Borsa I. (szerk.) (2001): Zsigmondkori oklevéltár VII. (1419-1420). Magyar Országos Levéltár kiadványai II., Forráskiadványok 37. Magyar Országos Levéltár, Budapest.

Mező Ferenc (2014): PSYOPS - avagy: kalandozás a hadak útján, a pszichológia ösvényein, a történelem útvesztôiiben. Kocka Kör, Debrecen.

Palacký, F. (1984): A huszitiżmus története. Európa Kiadó, Budapest. 
Pósán L. (2007): Ferdinand Opll: A középkori város kialakulása. Klió, 2007. (16. évf.) 2. sz. 110. Letöltés: 2020.04.24. Web: http:// www. c3.hu/ klio/klio072/klio110.htm

Pósán L. (2019): Magyarország és a Német Lovagrend a középkorban. Kapitális Kft., Debrecen. 209-258.

Rácz L. (2006): A Kárpát-medence éghajlattörténete a közép- és kora-újkorban. In: Ferenczi L. (szerk.): Magyar középkori gazdaság- és pénztörténet: Jegyzet és forrásgyüjtemény. Bölcsész Konzorcium, Budapest. 31-51. Letöltés: 2020.04.22. Web: http://gepeskonyv.btk.elte.hu/adatok/To rtenelem $/ 83 \mathrm{~K} \%$ E1lnoki/GY\%D6NGY \%D6SSY $\% 20 \mathrm{~K} \% \mathrm{D} 6 \mathrm{NYV} / 03 \% 20 \mathrm{RACZ}$. pdf

Rázsó Gy. (1960): A zsoldosintézmény kezdetei Magyarországon a XIV. században. Hadtörténelmi Közlemények, Budapest. 1960. (9. évf.) 2. sz.,107-143. letöltés: 2020.04.24. Web: http://epa.oszk.hu/00000/00018/ 00096/pdf/EPA00018 hadtortenelmi_19 $60 \quad 02 \quad 107-143 . p d f$

Szilágyi Zs. (2004): Felelőtlen Napóleon? avagy az 1812-es tél. In: Adsumus II. Tanulmányok a IV. Eötvös Konferencia elóadásaiból. Eötvös József Collegium, Budapest, 2004. 43-50.

Szun Ce (2017): A hadviselés törvényei. Az ókori művet fordította: Tőkei Ferenc. Letöltés: 2020.04.29. Web: https://mek.oszk.hu/ 01300/01345/01345.htm

Tóth D. (2016): Létszám, ellátmány, utánpótlás. Szempontok a középkori magyar haderő vizsgálatához. In: Farkas Cs., Lados T., Ribi A. és Uhrin D. (szerk.): Magister Historiae II. Válogatott tanulmányok a 2014-ben és 2015-ben megrendezett középkorral foglalkozó, mesterszakos ballgatói konferenciák elöadásaiból. ELTE BTK Történelemtudományi Doktori Iskola. Budapest. 142157.

Tóth D. (2017): A huszita típusú hadiszekér alkalmazásának összehasonlítása a 20. század első harmadának mobilizálásra vonatkozó elgondolásaival. Katonai logisztika, 2017. (25. évf.) 1. sz., 220-242.

Tóth D. (2018): Mennyibe kerülhetett egy zsoldos fenntartása a középkor végi $\mathrm{Ma}$ gyarországon? Az $M H$ Összhaderönemi Parancsnokság Szakmai-Tudományos Folyóirata. 2018. p. 132-142.

Tóth Z. (1916): A huszita eredetű szekérvár. Hadtörténelmi Közlemények. 1916. (17. évf.) 1. sz. 265-311. Letöltés: 2020.04.24. Web http://epa.oszk.hu/00000/00018/00178 Lpdf/EPA00018 hadtortenelmi $1916 \quad 26$ 5-311.pdf

Tóth-Szabó P. (1917): A cseh-buszita mozgalmak és uralom története Magyarországon. Hornyánszky Könyvnyomda. 55-83. Letöltés: 2020.04.22. Web: https://archive.org/ details/csehhuszitamozga00tt/page/52/ mode/2up

Turnbull, S. (2004): The Hussite Wars 14191436. Oxford: Osprey Publishing Ltd.

Turnock, D. (1989): Eastern Europe An Historical Geography 1815-1945. London and New York: Routledge. 6-113.

Veszprémy L. és Somogyi G. (2014): Károly Róbert 1330. évi havasalföldi hadjárata és az ún. posadai csata historiográfiája. Hadtörténelmi közlemények, 2014. (127. évf.) 1. sz., 23-40. Letöltés: 2020.04.24. Web: http://epa.oszk.hu/00000/00018/00030 $\angle$ pdf/EPA00018 hadtortenelmi 20141 023-040.pdf 